\title{
MIIP is Downregulated in Gastric Cancer and Its Forced Expression Inhibits Proliferation and Invasion of Gastric Cancer Cells in vitro and in vivo [Corrigendum]
}

Sun D, Wang Y, Jiang S, Wang G, Xin Y Onco Targets Ther. 2018;11:8951-8964.

The authors have advised due to an error at the time of figure assembly, Figure 3F on page 8959 is incorrect. The correct Figure 3 is shown below.
The authors apologize for this error and advise it does not affect the results of the paper.
A
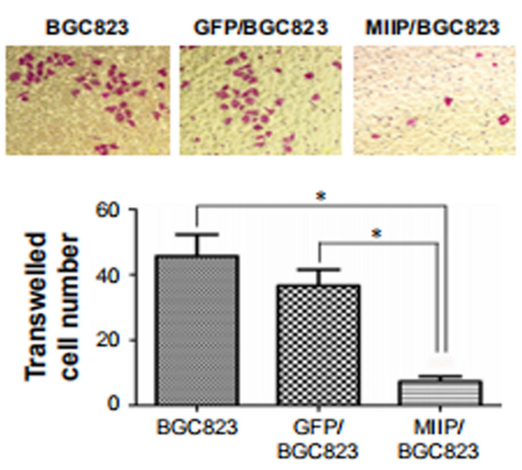

B
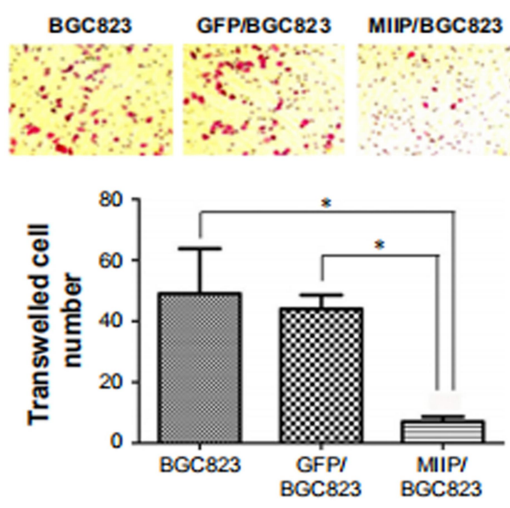

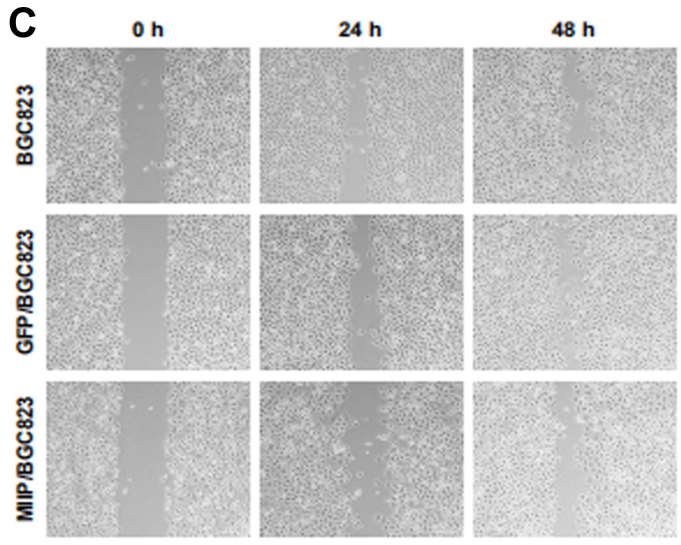

D

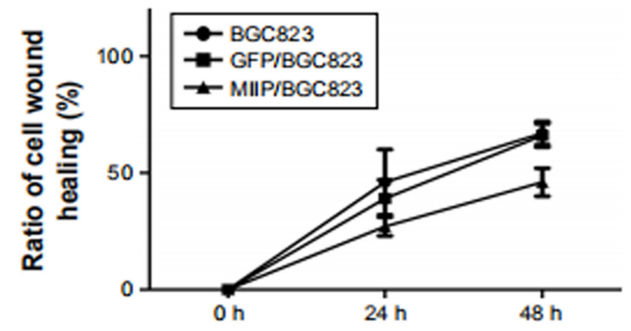

Figure 3 Continued 
E
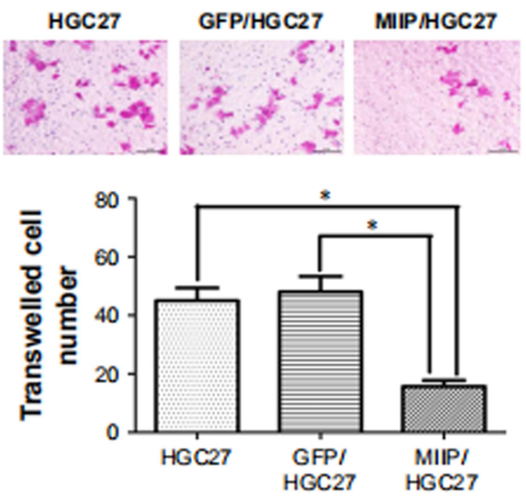

G
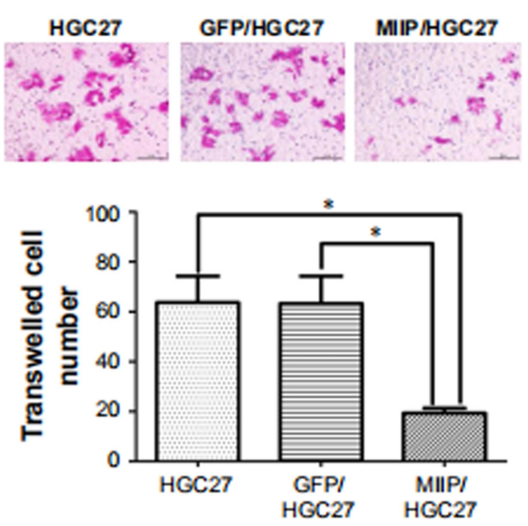

$\mathbf{F}$

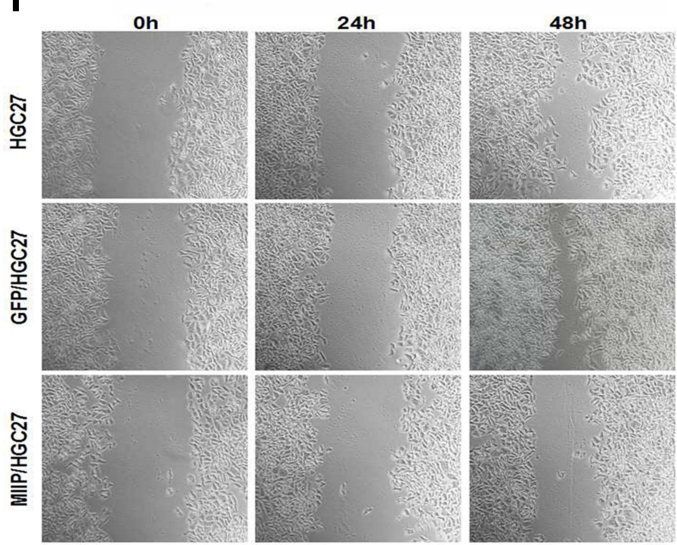

H

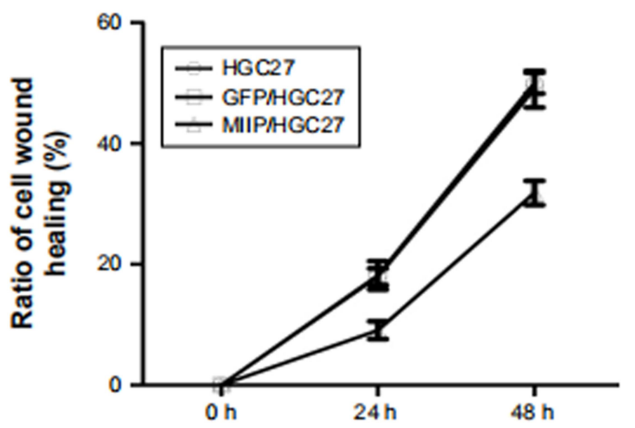

Figure 3 MIIP suppressed the invasion and migration of gastric cancer cells in vitro.

Notes: (A, E) Representative images showing the cells invading through the Transwell membrane in BGC823 cells (A) and HGC27 cells (E). Original magnification $\times 200$. The bar graph shows the summary data on numbers of invaded cell. (B, G) Representative images showing the BGC823 cells (B) and HGC27 cells (G) migrated to the lower chamber in the Transwell assay. The bar graph shows the summary data on numbers of migrated cells. Original magnification $\times 200 ; n=3$ for each group; $* P<0.05$. (C, F) The wound-healing assay was used to evaluate the migration properties of BGC823 (C) and HGC27 (F) cells. Cells were photographed at 0, 24, and 48 hours after wounding (original magnification $\times$ I00). Cells between the wound edges were the cells that migrated to the wound area. (D, H) The migration ability of cells in the MIIP/BGC823 and MIIP/HGC27 groups was significantly decreased compared with the control groups ( $\mathrm{n}=3$ for each group; $* P<0.05$ ). The curves showed the ratio of cell wound healing from 0 hour to 48 hours. BGC823 and $\mathrm{HGC27}$ denote cells without transfection. While GFP/BGC823 and GFP/HGC27 denote cells transfected with GFP-expressing empty vector, MIIP/BGC823 and MIIP/HGC27 denote cells transfected with GFP- and MIIP-coexpressing vector.

Abbreviation: MIIP, migration and invasion inhibitory protein.

\section{Publish your work in this journal}

OncoTargets and Therapy is an international, peer-reviewed, open access journal focusing on the pathological basis of all cancers, potential targets for therapy and treatment protocols employed to improve the management of cancer patients. The journal also focuses on the impact of management programs and new therapeutic agents and protocols on patient perspectives such as quality of life, adherence and satisfaction. The manuscript management system is completely online and includes a very quick and fair peer-review system, which is all easy to use. Visit http://www.dovepress.com/ testimonials.php to read real quotes from published authors. 